\title{
First Record of an Indian Roofed Turtle, Pangshura tecta (Gray 1830), from Delhi, India
}

\author{
Gaurav Barhadiya and Faiyaz A. Khudsar \\ Centre for Environmental Management of Degraded Ecosystems, School of Environmental Studies, \\ University of Delhi, Delhi - 110 007, India (Gaurav7wild7@gmail.com)
}

$\mathrm{I}$ ndian Roofed Turtles (Pangshura tecta) are fully aquatic and inhabit freshwater with plenty of aquatic vegetation, on which these herbivorous turtles feed (Baruah et al. 2016). It is a less active species and comparatively a poor swimmer. Little is known about this relatively weak swimmer's breeding habits other than clutches typically consist of 4-10 eggs (Baruah et. al 2016). The species is widely distributed in northern India, but has not been reported from Delhi (Husain 1997).

In September 2018, we encountered a turtle with characters of P. tecta (Fig. 1) in Serpentine Lake of the Kamla Nehru

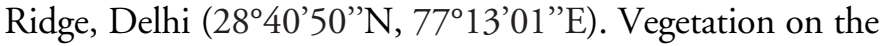
Kamla Nehru Ridge is a combination of dry thorny scrub dominated by species of Acacia and moist deciduous forest (Barhadiya 2016). We recorded morphological characters as follows: plastron length $=8.2 \mathrm{~cm}$; head moderately small and pointed; carapace elevated and oval with a distinct red vertebral keel that was spiked on vertebral III; neck with distinct yellow stripes, reddish crescent-shaped markings behind the eyes; fore- and hindlimbs spotted; digits webbed. Based on descriptions in Smith (1933), Hossain et al. (2013), and Baruah et al. (2016), we confirmed the identity of the turtle as P. tecta. This is the first record of the species from Delhi.

\section{Acknowledgements}

We are extremely thankful to Prof. C.R. Babu, the principal investigator of the Biodiversity Parks Programme for his continuous support, encouragement, and guidance. The authors specially thank Dr. Debanik Mukherjee, Field Biologist, Aravalli Biodiversity Park for confirming the identity of the turtle. We also thank Dr. A.K Singh, Scientist in charge, and Mr. Harmeek Singh, Supervisor, of Kamla Nehru Ridge, CEMDE for their help and support.

\section{Literature Cited}

Barhadiya, G. 2016. Biodiversity Assessment of Kamla Nehru Ridge. Unpublished M.Sc. dissertation, Department of Environmental Studies, University of Delhi, Delhi, India.
Baruah, C., P. Devi, and D.K. Sharma. 2016. Comparative morphometry and biogeography of the freshwater turtles of genus Pangshura (Testudines: Geoemydidae: Pangshura). International Journal of Pure and Applied Zoology 4: $107-123$

Hossain, M.L., S.U. Sarker, and N.J. Sarker. 2013. Morphometry of Indian Roofed Turtle, Pangshura tecta (Gray 1831) in Bangladesh. Bangladesh Journal of Zoology 41: 207-215.

Husain, A. 1997. Reptilia, pp. 665-698. In: J.R.B. Alfred (ed.), Fauna of Delhi. Zoological Survey of India, Dehradun.

Smith, M.A. 1933. The Fauna of British India, Ceylon and Burma, Including the Whole of the Indo-Chinese Sub-region. Reptilia and Amphibia. Vol. I.-Loricata and Testudines. Taylor and Francis, London.
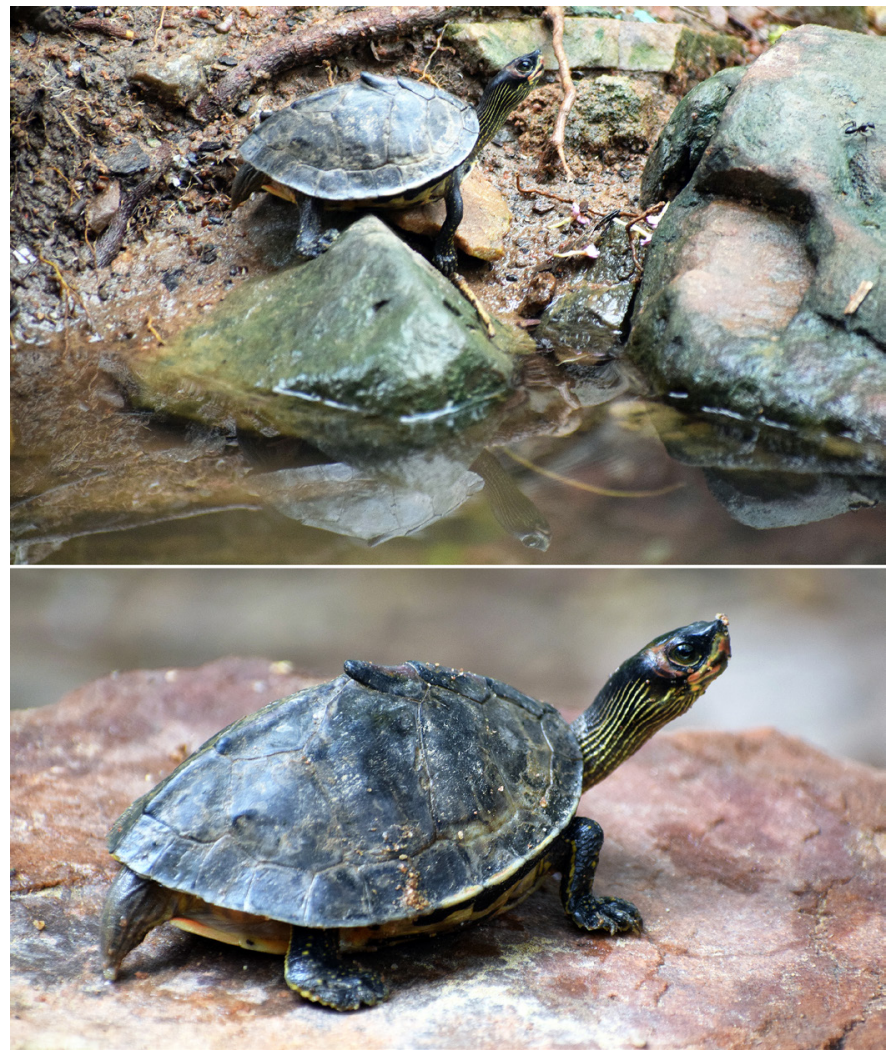

Fig. 1. Indian Roofed Turtle (Pangshura tecta) found in Serpentine Lake, Kamla Nehru Ridge, Delhi, India. Photographs by Gaurav Barhadiya. 